\title{
Total Phenolic Content, Antioxidant and Antimicrobial Properties of Pleurotus ostreatus Grown on Lime (Tilia Tomentosa) Leaves
}

\author{
Ihlamur (Tılıa tomentosa) Yapraklarında Üretıilen Pleurotus \\ ostreatus Mantarının Toplam Fenolık Madde Mıktarı, Antioksidan \\ ve Antimikrobiyal Özellikleri
}

Research Artıcle

Ayşenur Yılmaz ${ }^{1 *}$, Sibel Yıldız', Sana Tabbouche ${ }^{2}$, Ali Osman Kılıç ${ }^{2}$, Zehra Can ${ }^{3}$

${ }^{1}$ Karadeniz Technical University, Forest Faculty, Forest Indusrty Engineering, Trabzon, Turkey.

${ }^{2}$ Karadeniz Technical University, Faculty of Medicine, Department of Medical Microbiology, Trabzon, Turkey.

${ }^{3}$ Giresun University, Şebinkarahisar Vocational School of Technical Sciences, Food Technology, Giresun, Turkey.

\section{ABSTRACT}

\begin{abstract}
n this study, the posibility of using of waste lime leaves in Pleurotus ostretatus cultivation was investigated. After a successful harvest, total phenolic content, antioxidant and antimicrobial properties of mushrooms was determined. According to the test results; yield was 15\%, biological efficiency was $30 \%$. The total phenolic content was $151.4 \pm 0.001 \mathrm{mg} \mathrm{GAE} / 100 \mathrm{~g}$, the antioxidant activity was $2,508 \pm 0.056 \mu \mathrm{mol} \mathrm{FeSO} .7 \mathrm{H}_{2} \mathrm{O} / \mathrm{g}$. Additionally; methanolic extract of Pleurotus ostreatus mushroom showed inhibitory effect against Klebsiella pneumonia and Acinetobacter haemolyticus bacteria. As a result, Tilia Tomentesa's leaves are suitable raw material with satisfactory medical properties for the Pleurotus ostretaus cultivation.
\end{abstract}

\section{Key Words}

Antimicrobial, Antioxidant, Lime leaves, Pleurotus Ostreatus.

\section{ÖZET}

\begin{abstract}
Sunulan bu çalışmanın amacı, atık ıhlamur yapraklarının Pleurotus ostreatus mantarı kültivasyonunda $\checkmark$ kullanılabilirliğini araştırmaktır. Başarılı bir hasattan sonra, mantarların toplam fenolik madde miktarları, antioksidan ve antimikrobiyal özellikleri belirlenmiştir. Sonuçlara göre, verim \%15, biyolojik etkinlik \%30, toplam fenol miktarı $1.514 \pm 0.001 \mathrm{mg} \mathrm{GAE} / \mathrm{g}$, antioksidan aktivitesi $2.508 \pm 0.056 \mu \mathrm{mol} \mathrm{FeSO}_{4} .7 \mathrm{H}_{2} \mathrm{O} / \mathrm{g}$ olarak hesaplanmıştır. Ayrıca Pleurotus ostreatus mantarı metanolik özütleri Klebsiella pneumonia ve Acinetobacter haemolyticus bakterilerine karşı inhibitor etki göstermiştir. Sonuç olarak, Tilia tomentosa yaprakları tıbbi özelliklere sahip Pleurotus ostreatus kültivasyonu için uygun bir hammaddedir.
\end{abstract}

Anahtar Kelimeler

Antimikrobiyal, antioksidan, Ihlamur yaprakları, Pleurotus ostreatus.

Article History: Received: Jun 22, 2015; Revised: Dec 12, 2015; Accepted: Mar 20, 2016; Available Online: Apr 1, 2016. Dol: $10.15671 /$ HJBC.20184417585

Correspondence to: A. Yılmaz; Karadeniz Technical University, Forest Faculty, Forest Indusrty Engineering, Trabzon, Turkey. 


\section{INTRODUCTION}

There are some mushroom species which cultivated, especially production and comsuption of Pleurotus ostretaus rises day to day [1]. P. ostreatus is a prospective source of valuable food protein, and an organism with the ability to utilize various lignocellulosic materials [2,3]. Soybean, sorghum, peanut and wheat straw [4], leaves of hazelnut, leaves of European leaves, waste paper [3], cotton straw, lentil straw, rice bran [5] etc. can be used as substrate for cultivation on Pleurotus spp.

Mushrooms [6-8] and plants (fruits, vegetables, medicinal herbs, etc.) [9-14] may contain a wide variety of free radical scavenging molecules, such as phenolic compounds (e.g. phenolic acids, flavonoids, quinones, coumarins, lignans, stilbenes, tannins), nitrogen compounds (alkaloids, amines, betalains), vitamins, terpenoids (including carotenoids), and some other endogenous metabolites, which are rich in antioxidant activity. Antioxidants may help the body to protect itself against various types of oxidative damage caused by reactive oxygen species, which are linked to a variety of diseases including cancer, vascular diseases, diabetes, arthritis, and ageing process $[15,16]$. There are two basic categories of antioxidants, natural and synthetic. Recently, interest has increased considerably in finding naturally occurring antioxidants for use in foods or medicinal materials to replace synthetic antioxidants, which are being restricted due to their carcinogenicity $[17,18]$ and mushrooms is reported that natural antioxidans [19-22].

In recent years, multiple drug resistance in human pathogenic microorganisms has developed, due to indiscriminate use of commercial antimicrobial drugs commonly used in the treatment of infectious diseases. This situation has forced scientists to search for new antimicrobial substances from various plants which are good sources of novel antimicrobial chemotherapeutic agents [23,24] Mushroom species have been shown to possess antagonistic effects against bacteria, fungi, viruses and cancer [25-27].
The main objectives of this study were: (i) to investigate the posibility of using of waste lime leaves in cultivation of Pleurotus ostretatus and calculate yield and biological efficiency, (ii) to determine total phenolic content by FolinCiocalteu reagent and antioxidant properties by FRAP essay and (iii) to investigate the antimicrobial activity of methanolic extract of cultivated $P$. ostreatus by agar well diffusion method against some of bacteria and one yeast.

\section{MATERIALS and METHODS Materials}

P. ostreatus spawn was obtained from Agroma mycel, Denizli. Tilia tomentasa waste leaves were collected from Karadeniz Technical University Campus. Beech sawdust (control sample) were obtained from workshop of Forest Industry Engineering, Karadeniz Technical University.

\section{Substrate Preparation}

Tilia tomentasa's leaves and beech sawdust moistened with water until $70-80 \%$ and autoclaved $121^{\circ} \mathrm{C}$ for $1.5 \mathrm{~h}$. After cooling the substrates to $20^{\circ} \mathrm{C}$, they were placed in nylon bags of $1 \mathrm{~kg}(40 \times 60 \mathrm{~cm})$ and inoculated by spreading spawn on the surface of the substrate with a weight percentage of about $3 \%$ of the wet weight of compost. Subsrate condition was carried out in four replications. Each nylon bags were inoculated in mushroom growing laboratuary (10$15^{\circ} \mathrm{C}, 70-80 \%$ relative humidity). After 13 days, beech sawdust (control subsrate) and after 19 days lime leaves were completely colonized by the mycelium. Harvesting was done in fifth week and the fruit bodies's stipe and cap was calculated and weighed.

\section{Yield and Biological Efficiency}

Mushroom yield (g) was calculated by division of fresh weight of fruit bodies obtained from each one bag to dry weight of 1-kg compost [28]. Biological efficiencies was defined as the percentage ratio of the fresh weight of harvested mushrooms over the dry weight of substrateas [29]. 


\section{Total Phenolic Content and Antioxidant Activity}

\section{Sample Preparing}

$P$. ostreatus divided into five samples and dried $40^{\circ} \mathrm{C}$ before analysis. $4 \mathrm{~g}$ dried sample was extracted with $40 \mathrm{~mL}$ methanol and shaked 150 rpm for $24 \mathrm{~h}$ then filtered through Whatman No. 4 filter paper. Extracts were stored at $4^{\circ} \mathrm{C}$ for further use.

\section{Total Phenolic Content}

Total phenolic contents of the methanolic extracts were determined by Folin-Ciocalteu method using gallic acid standard [30]. The Folin assay was also based all phenolic contents including phenolic acids, flavonoids, and anthocyanins in the aquatic solution gives a blue colour complex whose maximum absorbance can be read at 760 $\mathrm{nm} .680 \mu \mathrm{L}$ distilled water and $20 \mu \mathrm{L}$ methanolic extract and $400 \mu \mathrm{L}$ of $0.5 \mathrm{~N}$ Folin-Ciocalteu regents were mixed with in a tube, vortexed for $2 \mathrm{~min}$, then $400 \mu \mathrm{L} \mathrm{Na} \mathrm{CO}_{3}(10 \%)$ was added and incubated for 2 hour. Following the incubation at room temperature, absorbance of the mixtures were measured at $760 \mathrm{~nm}$ on an ATI-Unicam UV-2 UV-VIS spectrophotometer (Cambridge, U.K.). The concentration of total phenolic compounds was calculated as mg of gallic acid equivalents per $\mathrm{g}$ of dry weight.

\section{Determination of Antioxidant Activity}

Antioxidant activity of all mushrooms was determined using the following one method.

\section{Ferric Reducing Antioxidant Power (FRAP) Assay}

The reducing ability of ferric tripyridyltriazine (FeIII-TPTZ) complex was used for total antioxidant capacity assay [31,32] with some modifications. Working FRAP reagent was prepared as required by mixing $300 \mathrm{mM}$ acetate buffer, pH 3.6 with $10 \mathrm{mM}$ TPTZ solution in $40 \mathrm{mM} \mathrm{HCl}$ and $20 \mathrm{mM}$ $\mathrm{FeCl}_{3} \cdot 6 \mathrm{H}_{2} \mathrm{O}$ solution. $3 \mathrm{~mL}$ freshly prepared FRAP reagent and $100 \mu \mathrm{L}$ of the samples were mixed and incubated in $4 \mathrm{~min}$ at $37^{\circ} \mathrm{C}$ and the absorbance was read at $593 \mathrm{~nm}$ against reagent blank containing distilled water. $\mathrm{FeSO}_{4} \cdot 7 \mathrm{H}_{2} \mathrm{O}$ was used a positive control. The ferric-reducing antioxidant power of the antioxidants in the extracts was calculated by comparison with $\mathrm{FeSO}_{4} \cdot 7 \mathrm{H}_{2} \mathrm{O}$ as $\mu \mathrm{mol} \mathrm{FeSO} \mathrm{S}_{4} \cdot 7 \mathrm{H}_{2} \mathrm{O} / \mathrm{g}$ dry weight of mushrooms.

\section{Antimicrobial Activity}

$P$. ostreatus extracts were tested for antimicrobial activity by agar-well diffusion method in accordance with the Clinical \& Laboratory Standards Institute (CLSI). Tested microorganisms were: Staphylococcus aureus ATCC 25923, Escherichia coli ATCC 25922, Pseudomonas aeruginosa ATCC 27853, Enterococcus faecalis ATCC 29212, Acinetobacter haemolyticus ATCC 19002, Klebsiella pneumoniae ATCC 13883, Salmonella Typhimirium ATCC 14028 and Candida albicans ATCC 10231. Microorganisms were obtained from Karadeniz Technical University, Department of Medical Microbiology, Faculty of Medicine Trabzon, Turkey.

\section{Microbial Suspension and Test Technique}

Colonies of bacteria were mixed with $5 \mathrm{~mL}$ of sterile isotonic sodium chloride solution for moderate opalescence. Microbial suspension turbidity was adjusted to a density equivalent to a 0.5 McFarland standard. The microbial suspension was distributed on Mueller Hinton agar in three different directions using sterile cotton swabs, then extarct, positive and negative (pure methanol) control $100 \mu$ l was filled into the wells of agar plates directly. The petri dishes were leaved for diffusion for $15 \mathrm{~min}$ then incubated at $37^{\circ} \mathrm{C}$ for 24 hours. Activity was determined by visual inspection and measurement of the diameter of clear inhibition zones around the agar-well.

\section{Statistical Analysis}

Total phenolic content and antioxidant analyses were performed in triplicates. The data were recorded as means 4 standard deviations and analyzed by using Statistical Package for Social Sciences (SPSS version 16.0)

\section{RESULTS and DISCUSSION}

\section{Yield and Biological Efficiency}

After the harvest, mushrooms morphological properties were calculated. Diameter of fruit bodies and stipe, length of stipe are given Table 1. 
Table 1. Morphological properties (cm) of mushrooms.

\begin{tabular}{cccc}
$\begin{array}{c}\text { Mushroom } \\
\text { substrate }\end{array}$ & $\begin{array}{c}\text { Diameter } \\
\text { of fruit } \\
\text { bodies }\end{array}$ & $\begin{array}{c}\text { Diameter } \\
\text { of stipe }\end{array}$ & $\begin{array}{c}\text { Length of } \\
\text { stipe }\end{array}$ \\
\hline $\begin{array}{c}\text { Lime } \\
\text { leaves }\end{array}$ & $5 \pm 2.3$ & $0.30 \pm 0.1$ & $0.95 \pm 0.3$ \\
\hline $\begin{array}{c}\text { Beech } \\
\text { sawdust }\end{array}$ & $5.2 \pm 1.2$ & $0.30 \pm 0.1$ & $0.9 \pm 0.25$ \\
\hline
\end{tabular}

Avarege diameter of mushrooms cap was 5.0 $\mathrm{cm}$, diameter of stipe was $0.30 \mathrm{~cm}$, length of stipe was $0.95 \mathrm{~cm}$. The results were founded similar with other studies $[36,37]$.

Yield and biological efficiency was calculated as $15 \%$, and $30 \%$ for $T$. tomentosa leaves, and for beech sawdust as $28 \%$ and $77 \%$, respectively and presented in Table 2 .

Table 2. Yield (\%) and biological efficiency (\%) of subsrates.

\begin{tabular}{ccc}
\hline Substrate & Yield & B. E. \\
\hline Lime leaves & 15 & 30 \\
\hline Beech sawdust & 28 & 77 \\
\hline
\end{tabular}

In the literature; yield of $P$. ostreatus was reported between 15\% [32], 4.63-45.4\% [33] and biological efficiency was reported between 0 $61 \%$ [34], 48.9-90.5\% [35] on different compost.

\section{Total Phenolic Content and Antioxidant Properties}

The Folin-Ciocalteu assay has been used for many years to measure of total phenolic contents in natural products, and the basic mechanism is an oxidation/reduction reaction $[38,39]$.

Total polyphenols were the major naturally occurring antioxidant components found in the methanolic extracts from wild edible mushrooms [40]. It is reported that phenolic compounds are capable of natural antioxidants. Phenolic compounds, stopping or preventing the free radical reactions preventing to the arise of many diseases such as cancer, heart disease and lung diseases [41]. Total phenolic content and antioxidant (FRAP) values of mushroom are given in Figure 1.

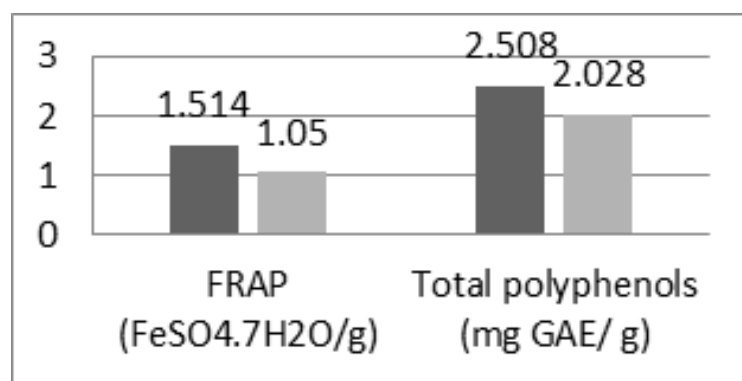

Mushroom grown on T.tomentasa leaves

Mushroom grown on beech sawdust

Figure 1. Total phenolic content and antioxidant (FRAP) values of mushroom.

In the prensent study, total phenolic content was determined that $1.514 \pm 0.001 \mathrm{mg} \mathrm{GAE} / \mathrm{g}$ for $P$. ostreatus grown on Tilia tomentosa leaves and $1.050 \pm 0.013 \mathrm{mg} \mathrm{GAE} / \mathrm{g}$ for $P$. ostreatus grown on beech sawdust. It can be conluded that substrate can effect total phenolic content of mushrooms. When the antioxidant activity values of the mushrooms determined by the FRAP method where compared with other vegatables, it was observed that mushroom rown on Tilia tomentosa leaves presented higher antioxidant activity than those reported for chicory (1.0912 $\mathrm{mg} \mathrm{GAE} / \mathrm{g}$ ), Lepidium sativum (1.2614 mg GAE/g) [42] and other mushroom's content was reported for Pleurotus eryngii ( $0.634 \pm 0.004 \mathrm{mg} \mathrm{GAE} / \mathrm{g})$, Cyttaria gunnii (0.761 $\pm 0.004 \mathrm{mg} \mathrm{GAE} / \mathrm{g})$ [43].

In this study, antioxidant activity was measured by the FRAP method, which measures the capacity of an antioxidant to reduce a $\mathrm{Fe}^{3+}$-TPTZ complex to $\mathrm{Fe}^{2+}-$ TPTZ. In this way, a higher $\mathrm{Fe}^{3+}-$ TPTZ reduction means a higher antioxidant activity. FRAP assay was used to determine antioxidant activity, as the technique is simple and quick. Higher FRAP values indicate higher antioxidant capacity, because FRAP values are based on reducing ferric ions, where antioxidants are the reducing agent. Antioxidants are compounds capable of donating a single electron or hydrogen atom for reduction. The reducing capacity of a compound may serve as a significant indicator of its potential antioxidant activity [44]. Frap activity of mushrooms grown 
on Tilia tomentosa leaves and beech sawdust was found as 2.508 \pm 0.056 and $2.0280 .009 \mu \mathrm{mol}$ $\mathrm{FeSO}_{4} \cdot 7 \mathrm{H}_{2} \mathrm{O} / \mathrm{g}$, respectively. $P$. ostreatus grown on Tilia tomentosa leaves value is higher than the other reported value of Pleurotus ostreatus $2.385 \mu \mathrm{mol} / \mathrm{g}$ [45]. Previous studies indicate that concentration, extraction methods and type of solvent affect antioxidant activity $[46,47]$.

\section{Antimicrobial Activity}

The tested fungi inhibit two gram-negative bacteria Klebsiella pneumoniae and Acinetobacter haemolyticus. Compared to other studies, $P$. ostreatus was able to inhibit E.coli, B. cerreus, Listeria innocua [47] and other gram positive or negative bacteria and fungi isolates [48]. Other mushrooms such as Morchella conica [49], Ramaria flava [50], Lycoperdon pusilum ve $L$. Giganteum [51] have also been reported to have antimicrobial activity against many microbes.

Based on the results of this study, it can be concluded that (i) waste lime leaves can be as substrat for Pleurotus ostreatus mushroom cultivation. Additionally; the leaves are also suitable raw material with satisfactory medical properties. $P$. ostreatus growing on linden leaves, (ii) have antioxidant potentials and (iii) antimicrobial activity. Further investigations would try different solvents, concantrations, other microorganisms and methods for assays.

\section{References}

1. i. Erkel, Dünyada ve Türkiye'de kültür mantarcılığının durumu, Türkiye 4. Yemeklik Mantar Kongresi, 1 (1992) 1.

2. D. Wang, A. Sakoda, M. Suziki, Biological efficiency and nutritional value of Pleurotus ostreatus cultivated on spent beer grain, Biosource Technol., 78 (2001) 293.

3. S. Yildiz, Ü.C. Yildiz, E.D. Gezer, A. Temiz, Some lignocellulosic wastes used as raw material in cultivation of the Pleurotus ostreatus culture mushroom, Process Biochemistry, 38 (2002) 301.

4. A. Yildiz, R. Demir, The effect of some plant materials on the growth and productivity of Pleurotus ostreatus (Jacq. ex. Fr.) Kum. var. salignus (Pers. ex. Fr.) Konr. et Maubl, Tr. J. of Biology, 22 (1996) 67.

5. S. Kırbağ, M. Akyüz, Evaluation of agricultural wastes for the cultivation of Pleurotus eryngii (DC. ex Fr.) Quel. var. ferulae Lanzi, African Journal of Biotechnology, 7 (2008) 3660.

6. I. Orhan, O. Ustun, Determination of total phenol content, antioxidant activity and acetylcholinesterase inhibition in selected mushrooms from Turkey, Journal of Food Composition and Analysis, 24 (2011) 386.
7. A.K., Saha, S. Acharya, A. Roy, 2012. Antioxidant level of wild edible mushroom: Pleurotus djamor (Fr.) Boedijn, Journal of Agricultural Technology, 8 (2012) 1343.

8. C.H. Gan, B. Nurul Amira, R. Asmah, Antioxidant analysis of different types of edible mushrooms (Agaricus bisporous and Agaricus brasiliensis), International Food Research Journal, 20 (2013) 1095.

9. R.A. Larson, The antioxidants of higher plants, Phytochemistry, 27 (1988) 969.

10. F. Shahidi, M. Naczk, Food phenolics: sources, chemistry, effects and applications, Technomic Pub. Co., Basel, Switzerland, (1995).

11. N. Cotelle, J.L. Bernier, J.P Catteau, J. Pommery, J.C. Wallet, E.M. Gaydou, Antioxidant properties of hydroxyflavones, Free Radical Biology and Medicine, 20 (1996) 35.

12. Y.S. Velioglu, G. Mazza, L. Gao, B.D. Oomah, Antioxidant activity and total phenolics in selected fruits, vegetables, and grain products, Journal of Agricultural and Food Chemistry, 46 (1998) 4113.

13. W. Zheng, S.Y. Wang, Antioxidant activity and phenolic compounds in selected herbs, J. Agric. Food Chem., 49 (2001) 5165.

14. Y. Cai, Q. Luob, M. Sun, H. Corkea, Antioxidant activity and phenolic compounds of 112 traditional Chinese medicinal plants associated with anticancer, Life Sciences, 74 (2004) 2157.

15. F. Shahidi, Natural antioxidants: chemistry, health effects and applications, AOCS press, USA (1997).

16. P. Rajalıngam, V. Mayakrıshnan, N. Abdullah, V. Sabaratnam, U.R Kuppusamy, In-vitro antioxidant properties of different varieties of mushrooms grown on rice grains, Agro FOOD Industry Hi Tech, 24 (2013) 66.

17. N. Ito, S. Fukushima, A. Hasegawa, M. Shibata, T. Ogiso, Carcinogenicity of butylated hydroxy anisole in F344 rats, J. Natl. Cancer Inst., 70 (1983) 343.

18. W. Zheng, S.Y. Wang, Antioxidant activity and phenolic compounds in selected herbs, Journal of Agricultural and Food Chemistry, 49 (2001) 5165.

19. L.M. Cheung, C.K. Cheung, V.E.C. Ooi, Antioxidant activity and total phenolics of edible mushroom extracts, Food Chem., 81 (2003) 249.

20. E. Mahfuz, I. Omerm, T. Ibrahim, T. Nuri, Determination of antioxidant activity and antioxidant compounds in wild edible mushrooms, J Food Compos Anal., 20 (2007) 337.

21. G. Sudha, S. Vadivukkarisi, R.B.I. Shree, P. Lakshmanan, Antioxidant activity of various extracts from an edible mushroom Pleurotus eous, Food Sci. Biotechnol., 21 (2012) 661.

22. D.R. Babu, G.N. Rao, Antioxidant properties and electrochemical behavior of cultivated commercial Indian edible mushrooms, J Food Sci Technol., 50 (2013) 301.

23. Y. Karaman, F. Şahin, M. Güllüce, H. Öğütçü, M. Şengül, A. Adıgüzel, Antimicrobial activity of aqueous and methanol extracts of Juniperus oxycedrus L, Journal of Ethnopharmacology, 85 (2003) 213.

24. A. Turkoglu, M.E. Duru, N. Mercan, I. Kivrak, K. Gezer, Antioxidant and antimicrobial activities of Laetiporus sulphureus (Bull.) Murrill, Food Chemistry, 101 (2007) 267. 
25. T.S. Tochikura, Nakashima H, Ohashi $Y, N$. Yamamoto Inhibition (in-vitro) of replication and of cytopathic effect of human immuno deficiency virus by an extract of the culture medium of Lentinus edodes mycelia, Med. Microbiol. Immunol., 177 (1998) 235.

26. S.G. Jonathan, I.O. Fasidi, Antimicrobial activities of two Nigerian edible macrofungi- Lycoperdon pusilum and Lycoperdon giganteus, Afr. J. Biom. Res., 6 (2003) 84.

27. E. Nwachukwu, H.O. Uzoeto, Antimicrobial activity of some local mushrooms on pathogenic isolates, Journal of Medicinal Plants Research Vol., 4 (2010) 2460.

28. G. Zervakis, C. Balis, Comparative study on the cultural characters of Pleurotus species under the influence of different substrates and fruiting temperatures, Micol Neotrop Appl., 5 (1992) 39.

29. S.T. Chang, O.W. Lau, K.Y. Cho, The cultivation and nutrial value of Pleurotus sajor-caju, European J. Appl. Microbiol, Biotechnol, 12 (1981) 58.

30. K. Slinkard, V.L. Singleton, Total phenol analyses: automation and comparison with manual methods, American Journal of Enology and Viticulture, 28 (1977) 49.

31. I.F.F. Benzie, J.J. Strain, Ferric reducing/antioxidant power assay: direct measure of total antioxidant activity of biological fluids and modified version for simultaneous measurement of total antioxidant power and ascorbic acid concentration, Methods in Enzymology, 299 (1999) 15.

32. D.M. Earnshaw, B.E. Dlamini, M.T., Masarirambi, Growth and yield of oyster mushroom (Pleurotus Ostreatus) grown on different substrates ammended with varying levels of wheat bran, International Journal of Life Sciences 1 (2012) 111.

33. M.I. Bhattı, M.M. Jıskanı, K.H. Wagan, M.A. Pathan, M.R. Magsı, Growth, Development and yield of oyster mushroom Pleurotus ostreatus (Jacq. Ex. Fr.) Kummer as affected by different spawn rates, Pak. J. Bot., 39 (2007) 2685.

34. M. Obodaı, J. Cleland-Okıne, K.A. Vowotor, Comparative study on the growth and yield of Pleurotus ostreatus mushroom on different lignocellulosic by products, Journal of Industrial Microbiology and Biotechnology, 30 (2003) 146.

35. M. Dahmardeh, M. Dahmardeh, R. Hossienabadi, H. Safarpoor, M. Dahmardeh, Comparative study on cultivation and yield performance of Pleurotus ostreatus (oyster mushroom) grown on different substrates (wheat straw and barley straw) and supplemented at various levels of spawn, Journal of Food, Agriculture and Environment, 8 (2010) 996.

36. H. Sher, M. Al-Yemeni, K. Khan, Cultivation of the oyster mushroom (Pleurotus ostreatus (jacq.) p. kumm.) in two different agroecological zones of Pakistan, African Journal of Biotechnology Vol., 10 (2011) 183.

37. D.P. Mamiro, P.S. Mamiro, Yield and mushroom size of Pleurotus ostreatus grown on rice straw basal substrate mixed and supplemented with various crop residues, Journal of Animal \& Plant Sciences, 10 (2011) 1211.
38. S. Kolayli, M. Kucuk, C. Duran, F. Candan, B. Dinçer, Chemical and antioxidant properties of Laurocerasus officinalis Roem (Cherry Laurel) fruit grown in the Black Sea region, J. Agric. Food Chem., 51 (2003) 7489.

39. L.M. Cheung, C.K.P Cheung, E.C.O. Vincent, Antioxidant activity and total phenolics of edible mushroom extracts, Food Chem., 81 (2003) 249.

40. A. Keleş, I. Koca, H. Gençcelep, Antioxidant properties of wild edible mushrooms, J Food Process Technol, 2 (2011) 2 .

41. N.M. Nizamlıoğlu, S. Nas, The phenolic compounds in vegetables and fruit; structures and their importance, Electronic Journal of Food Technologies, 5 (2010) 20.

42. B.B. Uyar, G.M Karadağ, N. Şanlıer, S. Günyel, Determining the amount of total phenolic compounds of some vegetables frequently used in our society, Food, 38 (2013) 23.

43. X. Zeng, J. Suwandi, J. Fuller, A. Doronila, K. Ng, Antioxidant capacity and mineral contents of edible wild Australian mushrooms, Food Science and Technology International, 18 (4) 367.

44. Meir, S., Kanner, J., Akiri, B., Hades, S.P., 1995. Determination and involvement of aqueous reducing compounds in oxidative defence sytems of various senescing leaves, J Agric Food Chem., 43 (2012) 1813.

45. A. Keleş, i. Koca, H. Gençcelep, Antioxidant properties of wild edible mushrooms, J. Food Process Technol., 2 (2011) 3.

46. H.S. Yim, F.Y. Chye, S.K. Ho, C.W. Ho, Phenolic profiles of selected edible wild mushrooms as affected by extraction solvent, time and temperature, As. J. Food Ag-Ind., 2 (2009) 392.

47. E. Vamanu, M. Ene, A. Vamanu, D. Smarandache, I. Sârbu, O. Popa, N. B beanu, S. Nı , B. Veaceslav, Antioxidant and antibacterial properties of the extracts from Pleurotus ostreatus EVFB1 and EVFB4, Romanian Biotechnological Letters 16 (2011) 40.

48. B.A. Iwalokun, U.A. Usen, A.A. Otunba, D.K. Olukoya, Comparative phytochemical evaluation, antimicrobial and antioxidant properties of Pleurotus Ostreatus, African Journal of Biotechnology, 6 (2007) 1732.

49. A. Turkoglu, I. Kivrak, N. Mercan, M.E. Duru, K. Gezer, $H$. Turkoglu, Antioxidant and antimicrobial activities of Morchella conica Pers, African Journal of Biotechnology, 5 (2006) 1146.

50. K. Gezer, M.E. Duru, I. Kivrak, A. Turkoglu, N. Mercan, H. Turkoglu, S. Gulcan, Free-radical scavenging capacity and antimicrobial activity of wild edible mushroom from Turkey, African Journal of Biotechnology, 5 (2006) 1924.

51. S.G. Jonathan, I.O. Fasıdı, 2003. Antimicrobial activities of two Nigerian edible macro-Fungılycoperdon Pusılum (Bat. Ex) and Lycoperdon Giganteum (Pers.), African Journal of Biomedical Research, 6 (2003) 85. 